\title{
Play On: Teaching Drama in an EFL Class
}

\author{
Abraham Panavelil Abraham \\ Professor- Department of Foreign Languages- The University of Nizwa- Sultanate of Oman \\ abrahampa1948@gmai1.com
}

\begin{abstract}
Using drama in the language classroom is an enormously rewarding and enjoyable activity for both the teachers and the students. This paper tries to examine the use of drama in an EFL class that consists of Arabic speaking Omani students of 18-20 years where English is taught as a foreign language. Its opening part looks at the importance of teaching language through literature and argues that the context and form of a literary work like drama arouses a lot of interest in meaningful use of that medium. This, in the words of George Eliot is "aesthetic teaching". The paper further discusses the role of the teacher who becomes rather a facilitator by way of supporting the students' efforts to establish an intensive relationship with the dramatic text without interfering too much in their act of creating meaning. The paper then takes a look at some useful strategies like integrative and communicative approaches, Pre-reading, While-reading and Post-reading activities that can be used while teaching a dramatic text. The question of how dramatic activities like role playing, mime etc. along with language exercises can be employed in the language class effectively will also be examined in the paper.
\end{abstract}

Keywords: communicative, integrative, Pre-reading, While-reading, Post-reading

\section{Introduction}

Using drama in an EFL/ESL classroom is a time-proven method of language learning and acquisition, for improving the four skills- listening, reading, writing and speaking, besides other language areas like vocabulary, grammar, and pronunciation. By adopting an integrated and communicative approach while teaching drama, a teacher can teach language more effectively, directly involving the students in the classroom activities. The story element in drama will create a very interesting and productive environment wherein the students will also be able to understand the universal values implicit in the dramatic texts. Robert Frost's One Act Play, "The Death of the Hired Man" (a dramatic version of his long poem) is used as a model here. [See Appendix]The reason for choosing this dramatic piece is because of the play's simple and straightforward style and the writer's expertise in handling the English language, all of which help the learners to participate in various language learning activities in the classroom.

\section{Why Drama?}

Beyond the sentence are both a challenge and an opportunity. Undoubtedly, literary works like drama provide a great deal of aesthetic, intellectual and emotional pleasure in that the playwright often seeks to express her/his vision of human experience through a creative and emotive use of language, which him turn gives much impetus and motivation for the students to learn the language in a more creative manner. One of the prerequisites for language learning is that students should have a feeling for the language; this can be achieved through creative and critical use of literary texts where they can experience language in use. According to Krashen(1999:46), for such experience to facilitate language learning, "the language experience needs to be contextualized and comprehensible" and Tomlinson (2008:35) points out that the learner needs to be motivated, relaxed, positive and engaged. 
All agree that a literary text (drama/poetry/fiction) can provide much rich experience and environment to language learners and give them ample opportunities to develop their power of interpreting a literary work - an important aspect of language learning. It also provides a rich source for both teachers and students of shared experiences that can stimulate discussion and critical thinking ability. Moody (1971:7) opines that literature also helps students improve their listening skills. The numerous topics related to life give students an opportunity for discussion that encourages oral practice. Often a teacher reads out passages from a literary text, or a record or a tape version of it is played for the purpose of bringing out its rhythmic quality and stimulating interest. Thus, when used orally, drama also can develop the students' listening ability. According to Obediat(1997:32), a literary work like drama can help students " to acquire a native-like competence in English, express their ideas in good English, learn the features of modern English, learn how the English linguistic system is used for communication, see how idiomatic expressions are used, speak clearly, precisely and concisely, and become more proficient in English, as well as become creative, critical and analytical learners".

Teachers can also help students in arranging play reading sessions and performing the play. This helps students to improve their speaking/reading/listening skills. The numerous topics related to life give students an opportunity for discussion that encourages oral practice, develops confidence in speaking English using new vocabulary items and expressions, thus enabling them to become more proficient in English as well as becoming creative, critical and analytical learners.

Collie and Slater (2000:30) point out the following reasons for using literature in a language class which is applicable to dramatic literature as well:

- It is authentic material

- It is helpful in cultural and language enrichment

- Students develop a lot of personal involvement

- There will be a lot of interaction in the class

According to Maley (1989: 12) the themes of literary texts are related to all cultures in spite of the different approaches of the writers- love, conflicts, death, human relationships, beliefs etc. These are subjects relevant to all human beings at all times, and so are universal.

\section{Choosing an Appropriate Text}

The main challenges in choosing a suitable play are:

- Finding out a play that is of relevance and interest to learners, taking into consideration the level of the students' comprehension

- Length of the play- it may be difficult to deal with full length plays or even Shakespearean plays which have quite a number of scenes and Acts, though they provide more contextual details, and development of character and plot. One Act Plays are the best options. One or two acts in a full length play is also possible.

- Cultural difficulty - texts should not be so culturally dense that outsiders feel excluded from understanding the essential meaning.

According to Duff and Maley (2007: 12-13), while selecting a literary text like drama, a teacher should ask the following questions:

- Is the subject matter likely to interest the students?

- Is the language level appropriate?

- Does it require much cultural or literary background knowledge?

- Is it culturally offensive in any way?

- Can it be easily exploited for language learning purposes?

\section{Integrated and Communicative Approach}


As in many third world countries, as in Oman, we have found that an integrative and communicative approach is the most useful method of teaching English language through drama. When we use this approach, it is found that the students are fully involved in the classroom. The teacher ceases to be a lecturer and instead becomes a facilitator. In this case, language skills will not be taught in isolation. On the contrary, they are taught in an integrated way, incorporating a set of text-based, student centered activities which as Collie and Slater(2000:28) suggest add fresh momentum into the teaching of drama by stimulating students' desire to read[or role playing]and by encouraging their responses". It should involve pre reading activities, interactive work on the select play, and follow up activities. Activities like predicting, gap filling, creative writing, role playing, integrating spelling with vocabulary, etc. are found very useful as these can establish necessary connections between language and literature which eventually make the teaching and learning of a dramatic text a very meaningful and productive enterprise. These activities not only create a challenging environment where students try to apply their mettle in the best possible way, but also call for a great deal of attention on the part of the teacher. To quote Dutta (2001:522) these type of activities help the students to have the "intuitive response of a practicing literary critic and the analytical tools of a practical linguist". Roman Jakobson's statement quoted in the beginning of this paper implies that language, the medium through which the writer brings out her/his creative output claims a closer attention than most teachers of literature are willing to devote themselves too.

In this approach, the classroom activities may be divided into three categories viz. "Pre- Reading Activities", "While- Reading Activities", and "Post- Reading Activities", Pre- reading activities are a sort of warming up which can provide a platform to elicit from students their feelings and responses to ideas and issues in aliterary text. "While- reading activities" aim at helping the students to experience the text holistically by developing a fruitful interaction between the text and the reader. Post- reading activities encourage students to reflect upon what they have read and they generate thoughtful interaction and deliberations on different issues both related to language and literature arising from the text.

In what follows, I shall try to discuss how some of these strategies that are adopted while teaching a dramatic text to the students who learn English as a foreign language. As mentioned earlier, Robert Frost's One Act Play "The Death of a Hired Man" (dramatized version of his poem under the same title) has been used as a model.

\section{(a) Pre- Reading Activities}

Before students read the play, it is useful to give them some background information about drama/One Act Play, discussing its important elements and how drama differs from novel /poetry/short story etc. The next stage is to try to involve the students in activities that will create the right attitude for receptivity and enjoyment and so result in their being inspired to read the play repeatedly. The activities demand that the students use their experience of the world, as well as their imagination and intelligence to guess what may happen in certain situations. Some properties of the text which may be used for drawing inferences are the title, illustrations, warmers, keywords and expressions, language exercises etc.

\section{(b) The title of the play}

The title of the play is always important as it often indicates the subject and/or theme of the text. The instructor announces that s/he is going to discuss the One Act Play "The Death of the Hired Man" and the students are asked to predict what is likely to happen in the play. Writing the title on the board, the instructor may ask a range of questions to elicit response from the students. In this case, some possible questions are: 
[1] What do you understand from the title of the play? Does it give any clue about what might happen in the play? Is the play going to have a sad ending or a happy ending? How did you guess?

[2] Does the definite article "The" in two places suggest anything to you?

[3] How would the meaning change if instead of "The" the article " $A$ " is used?

[4] What does a 'hired man' do?

\section{(c) Illustrations}

Having discussed the title, the instructor may now present an illustration that gives a pictorial expression of the play under discussion. This activity may provide important clues for predicting the content of the play. Many texts have front-cover illustrations. If these are not available, the teacher may help by having an artist prepare one. Even some students may have artistic talent for drawing/painting. In the present case, the illustration may show a farm house near farmlandwith cows and buffalos, a woman sitting in the courtyard waiting for someone, and from the distance, a man approaching carrying groceries.

After distributing the copies of the illustration, the instructor asks the students to derive from it as much information as possible about the background and setting of the play. While students study the picture, the instructor may ask questions like:

- What do you think is happening in the picture?

- Can you guess who could be the man in the picture? Justify your answer.

- Explain the background of this picture.

\section{(d) Warmers}

Pre-reading activities can be carried out with the help of some one-line warmers from the play or can be chosen from maxims, proverbs or quotations that are closely related to some aspects of the play's content and theme. Such "warmers" facilitate open discussion and elicit predictions of what the play will be about. They encourage a response to the theme and prompt a prior personal involvement with the subject represented in the text. Theteacher, choosing some closely related warmers, distributes them among students and asks them to express the idea contained in them. In order to highlight the theme of "The Death of the Hired Man", the instructor, for example, can select the following 'warmers'.

- A great man shows his greatness by the way he treats little men

- Gentleness and kindness will make our homes a paradise upon earth

- A little thought and a little kindness are often worth more than a great deal of money

- Home is where your heart is

- Home is the place where, when you have to go there, they have to take you in

- Nothing to look backward to with pride, nothing to look forward to with hope

Students may be asked to discuss in pairs or groups and write down briefly what they understand from the one-liners or maxims. The warmers give an opportunity for the students to discuss at a more concentrated level the possible meaning of the play.

\section{(e) Keywords and phrases}

Sometimes the play provides clues for predicting its theme or content through the vocabulary items or expressions used in the play. It is, therefore, rewarding to pay special attention to the structure, organization, selection and collocation of lexical items in the play. The words and collocated units that appear in the form of keywords, through a semantic link, help readers to predict what the atmosphere of the world inside the play is going to be like. The teacher, giving a list of particular words and expressions from the play, may ask students to imagine the connotative 
implications of the listed items. In the case of the present dramatic text, the instructor can give some of the following expressions, words/phrases.

Godammit, haying, depending on, fixed wages, bettering oneself, I'm done, ditch the meadows, jumbling words, studying like violin, kinfolk, to make the bed, how much he is broken,

Students can be asked to discuss in groups or pairs the semantic implications of the above and try and reconstruct a play which may resemble the one they are going to read. These pre reading activities heighten student involvement in the play and stimulate their interest in reading it. At this juncture, the teacher may ask the students to start reading the first two pages of the play and engage them in "while reading activities" and during that time, the students are eagerly waiting to see to what extent their predictions are true.

\section{(f) While- reading activities}

Having done a set of pre-reading activities, students have brought themselves very close to the one act play that they are soon going to read. The while- reading activities therefore are designed to make the play more accessible by developing a purposeful interaction between the text and the reader. The following activities may be considered at this juncture.

- Reading the play in the class

- Language exercises

- Checking against predictions made about the play in the pre-reading activities

\section{(g) Reading the Play in the class}

The instructor can start reading the first few dialogues in the beginning and then the students may be asked to read the play in pairs. This activity will give students self-confidence and a sense of the whole play. It will also help them achieve a dramatic sense created by sound and intonation. Silent reading of the play can also be encouraged. Thereafter, students may be asked to prepare a list of dialogues that they find interesting and relevant to the play.

While reading the play, the students will notice that Silas is the hired man, working, on the farm of Warren who is a very strict person and who will never tolerate indiscipline. Silas, though old, is a good worker, but he goes away during the peak season of harvesting to work with someone else who can pay him some extra money. Warren is annoyed about this behavior of Silas, and so, has made up his mind not to take Silas back on the latter's return. Silas came back when Warren was not there, and Mary, Warren's wife, took Silas home as he was very sick at that time. Mary knows that for Silas this house is a home for him even though he has a rich brother. Mary tries to convince her husband that Silas has come back and that he said in his delirium that he wanted to clear the meadows and take care of the farm again. But Mary knows that his health is deteriorating and he cannot work again on the farm. She says, "He has come home to die". At this juncture, Warren also feels pity for Silas. Mary asks him to go and see for himself the condition of Silas. He goes to the kitchen where Silas was supposed to be sleeping and finds that Silas is dead. The sad ending of the story will create a touching impact in the minds of the students who now will be ready for some PostReading activities which will lead them to a deeper understanding and appreciation of the play.

\section{(h) Post- Reading Activities}

Post- Reading Activities are meant to create an appropriate situation for the learners where they can express their reactions to the play. These activities are supposed to deepen their understanding and generate interest in the creative use of language and provide opportunities for further interaction. Comprehension questions, language exercises, and other creative activities can be included at this stage.

Comprehension Questions 
These questions will help the teacher to examine what the students have made of the play that they have read. Based on the play, the teacher can ask the following questions related to the setting, plot, characters, theme etc. which will help the students in understanding the play better.

- When Warren comes home in the evening, Mary takes the market things from him and then draws him down to sit beside her on the wooden steps. Can you guess why she does this?

- "I won't have him back...what good is he at this age?" Who said these words? Explain the context. What do these words tell us about the speaker?

- Mary is depicted as a kind person in the play. Can you give some examples from the play that explain this trait in her?

- How did Mary help Silas when he came back very sick and weak?

- Who is Harold Wilson mentioned in the play and what is his connection with Silas?

- "I think he (Silas) has come home to die". Who said these words and what was the context? What do you think is the difference between "home" and "house"? What is the definition of "home" as stated in the play?

- Warren says, "Do you think Silas has a better claim on us...than on his brother?" What is his brother doing? It is not directly mentioned in the play why Silas does not go to his brother at the time when he is very sick? Can you make an inference?

- The play ends on a sad note with the death of Silas. Can you change the ending with a happy note? If "yes" what changes would you like to incorporate?

At this juncture, the teacher may divide the class into small groups and ask them to discuss these questions and ask the students to write the answers as home assignments.

\section{(i) Language Exercises}

The instructor also can introduce a variety of language exercises in order to develop students' language skills:

Vocabulary

Use the following words/expressions/phrases in sentences of your own:

- Musing on

- To sit beside

- To set it on

- Accomplishment

- To take one in

- To be kind

- Be surprised

- To be worn out

- To have some pity

- The fool of books

Students also can be asked to identify some colloquial/conversational expressions in the play like "Godammiit"," Shhh" etc

Change these questions that are asked in the play into normal statements:

- When was I ever anything but kind to him?

- What good is he?

- Who else will harbor him?

- What help he is there's no depending on?

Change the following from present tense to the past tense:

- Mary sits musing on the moon

- What is going on?

- He thinks he ought to earn a little pay 
- I don't think he expects that this time

- Silas says you'll have to have him back

- Those days trouble Silas like a dream

- I know that is Silas' one accomplishment

- He returns too soon, sits next to Mary, takes her hand and waits

\section{(j) Creative Activities}

Students may be involved in a whole range of creative activities designed to enhance their understanding and appreciation and improve their expressive and receptive skills. Some of the activities like rewriting the play with a happy ending (as mentioned in one of the comprehension questions above) can be tried out in the class with the guidance of the teacher. A playwright always wants his/her play to be performed. Using the stage directions (Usually incorporatedin parenthesis) the teacher can help the students to arrange a performance of the play for a larger audience.

\section{Conclusion}

A literary text- (drama, novel, or poetry) is a means of communication, a kind of language in use and as such comparable with other means of communication. It is language in action that can be put into effective use for teaching and learning English. One way to expand students' knowledge of varieties of English is through a literary text like a one act play and by this, the students are benefitted both linguistically and conceptually. By using some or all the strategies examined in the paper, students get an opportunity to make predictions, and check them against the actual happenings in the play. They also learn how to deduce meaning and form a semantic chain from the keywords examine how language is used to describe a setting and create desired effects. Moreover, they also learn how to work out ways of transferring the play and reconstructing its specific and literal meaning. Thus, with an awakened language sensitivity and improved literary insight, students gain the ability to look at drama as a work of creative expression and an aesthetic and effective way of learning the target language.

\section{References:}

[1] Collie, J \& S. Slater., Literature in the language classroom: A Resource Book of Ideasand Activities, Cambridge: OUP,( 2000)

[2] Duff A\& Maley. A (2007). Literature (Resource Book for Teachers), OUP

[3] Dutta, Sujit K., Teaching Poetry in the School Classroom...,CAUSE, Number 24, (2001)

[4] Eliot.G., Letters to Frederick Harrison, F.R. Leavis. Introduction to Silas Marner, Harmmod sworth: Penguin Books, (1866)

[5] Jakobson, R, Closing Statement: Linguistic and Poetics. Sebeok, T (ed.) Style in Language Mass, MIT Press, (1970)

[6] Krashen, S., The Power of Rea. Englewood, NJ, (1993)

[7] Maley, A., Down from the Pedestal: Literature as Resource, Literature and Learner: Methodical Approaches. London: CUP, (1989) 
[8] Moody, H.L.B (1983). Approaches to the study of Literature: A Practitioner's View, Brumfit, C.J. (Ed.). Teaching Literature Overseas: Language -based Approaches. English Language Teaching Documents, 115. British Council

[9] Obediat. M., Language versus Literature in English Departments in Arab World, English Teaching Forum, (1997)

[10] Tomlinson, B., English Language Learning Materials: A Critical Review: London: Continuum Press,(2008), https://doi.org/10.5040/9781474212182

\section{APPENDIX}

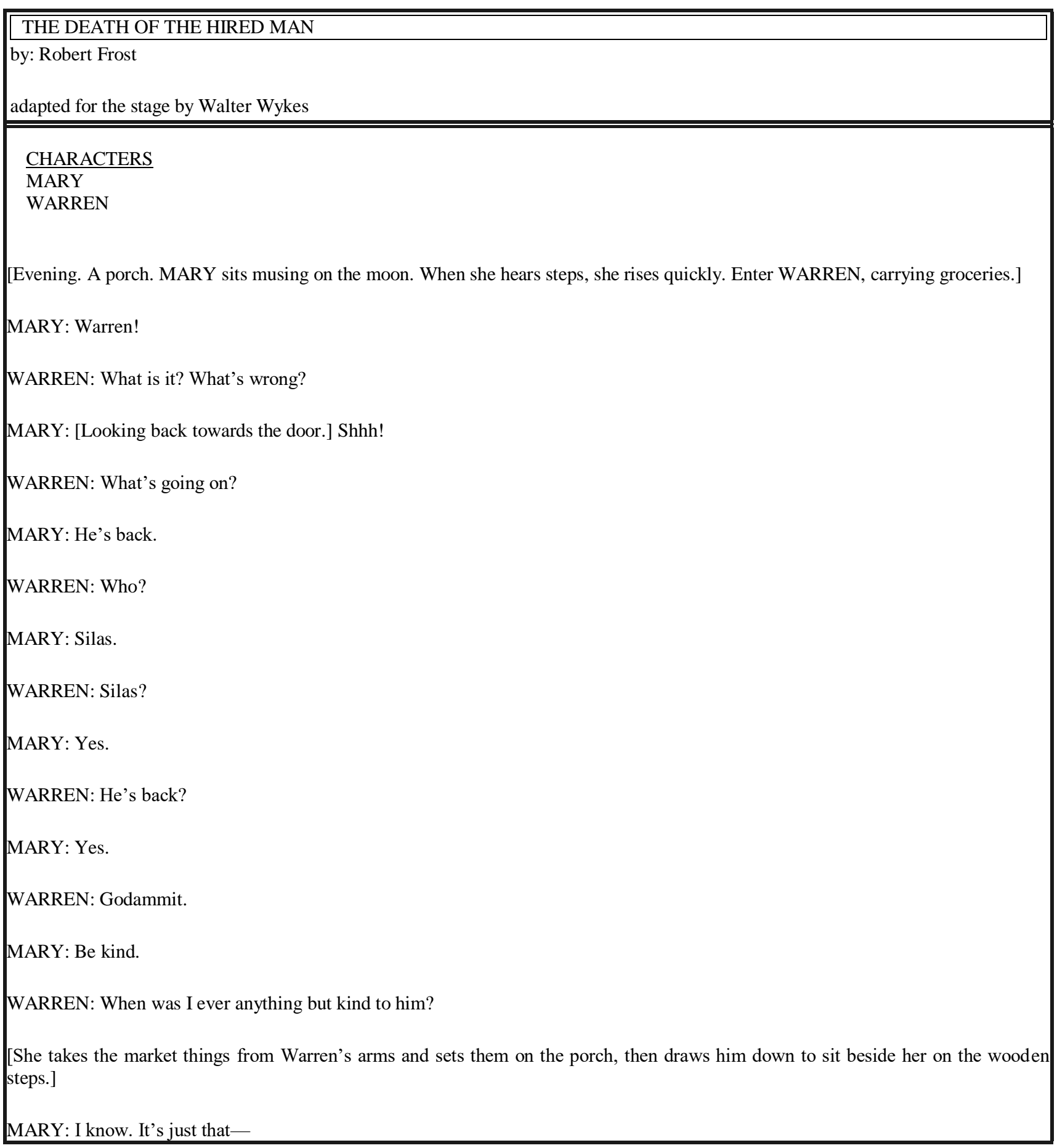


WARREN: I won't have him back. I told him so last haying, didn't I?

MARY: You did.

WARREN: If he left then, I said, that ended it.

MARY: I know, but-

WARREN: I can't keep ... I mean, what good is he? At his age-

MARY: Who else will harbor him?

WARREN: That's not our problem. What help he is there's no depending on. And when I need him most, off he goes every time!

MARY: He thinks he ought to earn a little pay.

WARREN: Oh, does he?

MARY: Just a little. Enough at least to buy tobacco, so he won't have to beg and be beholden. [Warren sighs and lowers his head. MARY puts a hand on his arm.] It doesn't have to be much.

[Pause.]

WARREN: All right. But I can’t afford to pay any fixed wages.

MARY: I don't think he expects that this time.

WARREN: I wouldn't mind his bettering himself if that's what it was. But you can bet when he starts off like that it's just someone trying to coax him off with a little pocket-change. Then every winter he comes back. I'm done, I tell you. This is the last-

MARY: Shhh! Not so loud. He'll hear you.

WARREN: Good. I want him to hear. He'll have to sooner or later.

MARY: Not now. He's worn out.

WARREN: Where is he?

MARY: Asleep by the stove.

WARREN: By the stove?

MARY: When I came up from Rowe's I found him here, huddled against the barn-door. He was a miserable sight. It scared me. Don't smile like that - I didn't recognize him. I wasn't looking for him, and he's changed. Wait till you see.

WARREN: Where did you say he'd been?

MARY: He didn't say. I practically dragged him to the house, gave him tea and tried to make him smoke. I tried to make him talk about his travels, but nothing would do-he just kept nodding off.

WARREN: Probably drunk.

MARY: No.

WARREN: No?

MARY: I've seen him drunk. This was different. 
WARREN: And he didn't say anything?

MARY: Not much.

WARREN: Not much?

MARY: Hardly a word.

WARREN: There's something you're not telling me. What is it? [Pause.]Mary, confess. He said he'd come to ditch the meadow for me-didn't he?

MARY: Warren!

WARREN: Did he or didn't he? I just want to know.

MARY: Of course he did. [WARREN laughs.] What would you have him say? Surely you wouldn't grudge the poor old man some humble way to save his self-respect.

WARREN: I just thought maybe he'd come up with something new this time.

MARY: He added, if you really care to know, he meant to clear the upper pasture.

WARREN: I've heard that one too.

MARY: Warren, I wish you could have heard the way he jumbled everything. It shook me up. I stopped to look two or three times to see if he was talking in his sleep. He ran on and on about Harold Wilson-you remember Harold? The boy you had haying about four years ago?

WARREN: Sure. I remember.

MARY: He's finished school and now he's teaching in some college somewhere.

WARREN: Good for him.

MARY: Silas says you'll have to have him back.

WARREN: I guess Silas is running the place now.

MARY: He says the two of them will make a fine team for work-says they'll lay this farm smooth! The way he mixed that in with other things ... he seemed so confused.

WARREN: A little rest will cure that.

MARY: He liked young Wilson, I guess.

WARREN: You never would have known it the way they fought all through July in the blazing sun, Silas up on the cart to build the load, and Harold alongside to pitch it on. I took care to keep well out of earshot.

MARY: Well, those days trouble Silas like a dream.

WARREN: Strange how some things linger.

MARY: Harold's young college-boy assurance, you know, it got under his skin. After so many years, he still keeps finding good arguments he might have used.

WARREN: I sympathize. I know just how it feels to think of the right thing to say too late. Happens every time I argue with you.

MARY: It's more than that. 
WARREN: What do you mean?

MARY: He asked me what I thought of Harold's saying he studied Latin like the violin because he liked it.

WARREN: Good a reason as any.

MARY: He said he couldn't make the boy believe he could find water with a hazel prong — said that proved how much good school had ever done him. He thinks if he could have one more chance to teach him how to build a load of hay-

WARREN: I know, that's Silas' one accomplishment. He bundles every forkful in its place, then tags and numbers it for future reference, so he can find and easily dislodge it in the unloading. Silas does that well. He takes it out in bunches like big birds' nests. And you never see him standing on the hay when he's trying to lift, straining to lift himself.

MARY: He thinks if he could teach him that, he'd be some good perhaps to someone in the world — says he hates to see a boy the fool of books. He's so concerned for other folk, and nothing to look backward to with pride.

WARREN: Nothing to look forward to with hope, either.

MARY: His whole life like that. Then, and now, and never any different.[Silence. MARY stares up at the moon.] Warren, I think ... I] think he's come home to die. You needn't be afraid he'll leave you this time.

WARREN: [Gently mocking.] Home?

MARY: Yes. What else but home?

WARREN: It all depends on what you mean by home, I guess.

MARY: Of course he's nothing to us, any more than the old hound that came a stranger to us out of the woods, all broken and worn out from the trail. I think home is the place where, when you have to go there, they have to take you in.

[WARREN leans out and takes a step or two — picks up a little stick and brings it back. He breaks it in his hand and tosses it aside.]

WARREN: Silas has a better claim on us, you think, than on his brother? Just thirteen miles up the road. You can bet he's walked that far today. Why didn't he go there? His brother's rich, director in the bank or something.

MARY: He never told us that.

WARREN: We know it though.

MARY: His brother ought to help, of course. I'll talk to him if we can't keep things going.

WARREN: By right, he ought to take him in.

MARY: And he might be willing to - he may be better than appearances. But have some pity on Silas. Do you think if he had any pride in claiming kin or anything he looked for from his brother, he'd keep so still about him all this time?

WARREN: I wonder what's between them.

MARY: I can tell you. Silas is what he is—we wouldn't mind him—but he's just the kind that kinsfolk can't abide. He never did anything so very bad. And he don't know why he isn't quite as good as anyone else. He can't be made ashamed to please his brother, worthless though he is. He's got that much pride.

WARREN: You're right. That's probably all there is to it. I can't think Si ever hurt anyone.

MARY: No, but it hurt my heart tonight the way he lay and rolled his old head on that sharp-edged chair-back.

WARREN: He wouldn't let you put him on the lounge? 
MARY: No. Go and see what you can do-would you?

WARREN: All right.

MARY: I made the bed up for him there tonight. [WARREN rises.] You'll be surprised—how much he's broken. His working days are done, I think.

WARREN: Don't be so quick to say that.

MARY: I haven't been.

WARREN: He's a tough old goat.

MARY: Go, look—see for yourself. But, Warren ... [WARREN pauses.]Please remember how it is. He's come to help you ditch the meadow. He has a plan. You mustn't laugh at him.

WARREN: I won't.

MARY: He may not speak of it, and then he may.

[WARREN nods, holding the door.]

WARREN: You coming in?

MARY: No. Not yet. I'll sit here a while and see if that small sailing cloud will hit or miss the moon.

[Exit WARREN. Silence. He returns too soon—sits next to MARY, takes her hand and waits.]

MARY: Warren?

WARREN: Dead.

[Slow fade to black.]

$* * *$ 